\title{
Purification and Characterization of Extracellular and Intracellular Killer Toxin of Saccharomyces cerevisiae Strain 28
}

\author{
By P. PFEIFFER AND F. RADLER* \\ Institut für Mikrobiologie und Weinforschung der Johannes Gutenberg-Universität Mainz, \\ Postfach 3980, D-6500 Mainz, Federal Republic of Germany
}

(Received 19 January 1982; revised 5 April 1982)

\begin{abstract}
The extracellular killer toxin of Saccharomyces cerevisiae strain 28 was concentrated by ultrafiltration of culture supernatants and purified by ion-exchange chromatography. Polyacrylamide gradient gel electrophoresis in SDS indicated that the toxin is a glycoprotein with a molecular weight of about 16000 . Amino acid analysis revealed that the killer toxin contains 111 amino acid residues, equivalent to a molecular weight of 14045 ; the ratio of protein to carbohydrate in the molecule is therefore about 9 to 1 . The isoelectric point of the killer toxin was $\mathrm{pH} 4 \cdot 4$ to 4.5 . The toxin was unaffected by heating at $40^{\circ} \mathrm{C}$ for $1 \mathrm{~h}$ and its maximum activity against sensitive yeast cells was observed at $\mathrm{pH} 5 \cdot 0$. Cell-free extracts prepared from wellwashed cells of $S$. cerevisiae strain 28 were toxic for sensitive yeasts. The toxin present in these extracts (intracellular toxin) was partially purified by ultrafiltration and ion-exchange chromatography. The isoelectric points of the extracellular and intracellular killer toxin were similar.
\end{abstract}

\section{INTRODUCTION}

Certain strains of Saccharomyces cerevisiae excrete a substance (killer toxin) that kills other yeasts (sensitive strains) (Bevan \& Makower, 1963). The killer toxin was regarded as a protein by Woods \& Bevan (1968), and Palfree \& Bussey (1979) purified a killer toxin that was a protein. On the other hand, it has been reported that the killer toxin is glycoprotein in nature in $S$. cerevisiae (Bussey, 1972), Torulopsis glabrata (Bussey \& Skipper, 1975) and Pichia kluyveri (Middelbeek et al., 1979).

Hybridization experiments have shown that the ability of strains of Saccharomyces to produce a killer toxin is transferred by cytoplasmic factors (Makower \& Bevan, 1963). However, Woods et al. (1974) have observed a strain of $S$. cerevisiae in which cytoplasmic inheritance of the killer toxin does not occur. It is likely that the cytoplasmic inheritance of the killer toxin of $S$. cerevisiae depends on the presence of two different double-stranded molecules of RNA (dsRNA) that are localized in virus-like particles in the cytoplasm (Young \& Yagiu, 1978; Bussey, 1981). The smaller of the two RNA molecules (M dsRNA or P2) has been observed only in killer toxinproducing strains (killer strains). The M dsRNA is always accompanied by a larger RNA molecule (L dsRNA or P1) that is found in many yeast strains (Vodkin \& Fink, 1973; Herring \& Bevan, 1974; Vodkin et al., 1974). Apparently this L dsRNA contains the information for coding the major capsid polypeptides of the two virus-like particles that contain either L dsRNA or M dsRNA (Bostian et al., 1980). The size of the various molecules of dsRNA differs in different killer types $\left(K_{1}-K_{3}\right)$ and correlates with the characteristics of the toxins (Young \& Yagiu, 1978). Killer toxin alters the permeability of the plasma membrane in sensitive yeast cells, resulting in a liberation of $\mathrm{K}^{+}, \mathrm{ATP}$ and some amino acids (Bussey \& Sherman, 1973; Skipper \& Bussey, 1977); proton permeability is also affected (De la Pena et al., 1981).

This paper describes an effective procedure for the purification of the killer toxin of $S$. cerevisiae strain 28 , a strain for which the mechanism of inheritance of the killer character has not been determined. The method avoids harsh treatments, particularly the use of detergents, 
and so allows the composition of unaltered toxin to be investigated. Our primary objective was to determine whether the killer toxin of $S$. cerevisiae strain 28 is protein or glycoprotein in nature. We also investigated the possibility that significant levels of toxin might be found intracellularly.

\section{METHODS}

Micro-organisms. The yeast strains of Saccharomyces cerevisiae were from the collection of this Institute. The killer toxin-producing $S$. cerevisiae strain 28 was originally isolated by $\mathrm{Dr} \mathrm{I}$. Benda, Würzburg, from a grape. The sensitive yeast strain 67 (381) was from the Wissenschaftliche Station für Brauerei, München. Cultures were maintained on slopes of YEP-agar at $4{ }^{\circ} \mathrm{C}$.

Culture media. YEP-agar contained: glucose, $2 \%(\mathrm{w} / \mathrm{v}) ;$ peptone, $2 \%(\mathrm{w} / \mathrm{v})$; yeast extract, $1 \%(\mathrm{w} / \mathrm{v}) ;$ agar, $1.2 \%$ $(\mathrm{w} / \mathrm{v})$. Methylene blue agar was prepared according to Somers \& Bevan (1969). B-medium was a modified version of that described by Heerde \& Radler (1978) and contained: glucose, $5 \%(\mathrm{w} / \mathrm{v})$; DL-malate, $2 \%(\mathrm{w} / \mathrm{v})$; trisodium citrate dihydrate, $0.05 \%(\mathrm{w} / \mathrm{v})$; inositol, $0.004 \% . \mathrm{CaCl}_{2}$ was omitted because it is known to inhibit the action of the killer toxin (Kotani et al., 1977). The pH of the medium was adjusted to 5.0 with $\mathrm{KOH}$.

Detection of the activity of killer toxin. The method of Somers \& Bevan (1969) for the detection of killer toxin was used, with minor modifications. A sample containing $10^{5}$ cells of the sensitive yeast $S$. cerevisiae strain 67 was plated on methylene blue agar. The sample to be tested $(0.1 \mathrm{ml})$ was pipetted into wells $(10 \mathrm{~mm}$ diam.) cut into the agar. The plates were incubated for $5 \mathrm{~d}$ at $20^{\circ} \mathrm{C}$. The presence of killer toxin was indicated by inhibition zones around the wells (or the pieces of gel obtained after isoelectric focusing that were placed directly on the agar plates).

Production of the extracellular killer toxin. Saccharomyces cerevisiae strain 28 was grown at $20^{\circ} \mathrm{C}$ in modified Bmedium (20 1) in two $10 \mathrm{l}$ flasks that were slowly agitated by a magnetic stirrer. The flasks were closed with cotton plugs to allow the slow access of oxygen. After $3 \mathrm{~d}$ the yeast cells were removed by continuous centrifugation at $4{ }^{\circ} \mathrm{C}$. The supernatant was filtered through Seitz filter pads (type EK) and through an ultrafiltration membrane (Sartorius type SM 12136) with an exclusion limit of $10000 \mathrm{Dal}$. The total volume was thus concentrated to about $300 \mathrm{ml}$. This concentrate was filtered through a further ultrafiltration membrane (Amicon-PM 10). The final volume was about $10 \mathrm{ml}$ and corresponded to a 2000 -fold concentration of the killer toxin.

Purification of the killer toxin by ion-exchange chromatography. The concentrated and desalted supernatant containing $80 \times 10^{6}$ units of killer toxin $(212 \mathrm{mg}$ protein in $6 \mathrm{ml})$ was applied to a column $(12 \times 2.6 \mathrm{~cm})$ of Servacel cellulose P23. After washing with $0.01 \mathrm{M}$-citrate buffer, $\mathrm{pH} 3 \cdot 5$, a KCl gradient from 0 to $2 \mathrm{M}(400 \mathrm{ml})$ was applied and fractions of $6 \mathrm{ml}$ were collected.

Amino acid analysis. An automatic amino acid analyser (Beckman) was used. Acid and neutral amino acids were separated on a column ( $560-570 \mathrm{~mm} \times 9 \mathrm{~mm}$ ) of M-72 resin, and basic amino acids on a column $(77 \mathrm{~mm} \times 9 \mathrm{~mm})$ of M-81 resin. Cysteine was determined by carboxymethylation of the sample prior to hydrolysis and estimation of $S$-carboxymethylcysteine by amino acid analysis. The content of tryptophan was calculated from the absorbance $(280 \mathrm{~nm})$ of the protein and the absorbance of solutions of tryptophan, phenylalanine and tyrosine as described by Goodwin \& Morton (1946). This method was evaluated by analysing lysozyme; the results obtained were in good agreement with the known amino acid composition of this protein.

Isoelectric focusing in polyacrylamide. The method described by Vesterberg (1972) was used with the power supply ECPS 2000/300 and flat-bed equipment FBE 3000 (Pharmacia). The latter was cooled to $4{ }^{\circ} \mathrm{C}$ with a water thermostat (Haake). The acrylamide gel was prepared with Pharmalyte $\mathrm{pH}$ 3-10 according to the instructions of the supplier. For focusing, $2000 \mathrm{~V}$ were applied for $6 \mathrm{~h}$; the output was limited to $30 \mathrm{~W}$. After focusing, the $\mathrm{pH}$ gradient of the gel was measured with a surface $\mathrm{pH}$ electrode. Half of the gel was fixed in $12.5 \%(\mathrm{w} / \mathrm{v})$ trichloroacetic acid and stained with Coomassie brilliant blue $(0.2 \%, w / v$, Coomassie brilliant blue in water/ethanol/acetic acid, $45: 45: 10$ by vol.). The other half of the gel was cut into small strips and placed on inoculated methylene blue agar plates for testing the activity of killer toxin.

Isoelectric focusing in Sephadex-IEF. The flat-bed equipment FBE 3000 and the preparative IEF-kit (Pharmacia) were used with 9.4 $\mathrm{g}$ Sephadex-IEF and $12 \mathrm{ml}$ Pharmalyte, $\mathrm{pH} 2 \cdot 5-5$, for focusing $5 \mathrm{ml}$ dialysed yeast cell extract containing $200 \mathrm{mg}$ protein. The gel was prepared according to the instructions of the supplier. Focusing was done for $14 \mathrm{~h}$ at $4{ }^{\circ} \mathrm{C}$ with the potential controlled to an output of $40 \mathrm{~W}$. The gel was then cut into 27 strips with a set of mounted knives and each strip transferred to a test tube and extracted with $2 \mathrm{ml}$ distilled water. The $\mathrm{pH}$ of each supernatant was measured and its killer toxin activity determined.

Polyacrylamide gradient gel electrophoresis. Polyacrylamide gradient gels type PAA 4/30 and the flat-bed equipment FBE 3000 were used. The electrophoresis buffer contained $\left(1^{-1}\right): 10.9 \mathrm{~g}$ Tris, $4.9 \mathrm{~g}$ boric acid and $0.93 \mathrm{~g}$ EDTA. After pre-electrophoresis $(20 \mathrm{~min}, 70 \mathrm{~V}$ ), the samples (calibration proteins or $20 \mu \mathrm{g}$ protein of the toxin preparation) were applied to the gel and the potential was increased to $150 \mathrm{~V}$. After $14 \mathrm{~h}$ of electrophoresis the gels were fixed in $12.5 \%(\mathrm{w} / \mathrm{v})$ trichloroacetic acid for $1 \mathrm{~h}$. Coomassie brilliant blue $(0.02 \%, \mathrm{w} / \mathrm{v}$, in $7 \%, \mathrm{v} / \mathrm{v}$, acetic acid) was used for staining overnight. The gel was destained with $7 \%(\mathrm{v} / \mathrm{v})$ acetic acid. 
$S D S$-polyacrylamide gradient gel electrophoresis. The procedure (according to the principle of Weber \& Osborn, 1969) was similar to that for polyacrylamide gradient gel electrophoresis described above. Electrode buffer contained $\left(1^{-1}\right): 4.5 \mathrm{~g}$ Tris, $1.65 \mathrm{~g}$ sodium acetate, $0.75 \mathrm{~g}$ Titriplex III and $2 \mathrm{~g}$ SDS. Sample buffer contained $\left(1^{-1}\right)$ : $1.21 \mathrm{~g}$ Tris (adjusted to $\mathrm{pH} 8.0$ with $\mathrm{HCl}$ ), $0.372 \mathrm{~g}$ Titriplex III, $25 \mathrm{~g}$ SDS and $50 \mathrm{~g}$ mercaptoethanol. After preelectrophoresis $(1 \mathrm{~h}, 70 \mathrm{~V})$ the samples were applied to the gels. The potential was held at $300 \mathrm{~V}$ for $10 \mathrm{~min}$, then continued for $6 \mathrm{~h}$ at $150 \mathrm{~V}$. For fixation a solution of $25 \%(\mathrm{v} / \mathrm{v}) 2$-propanol and $10 \%(\mathrm{v} / \mathrm{v})$ acetic acid in water was used. Glycoprotein was detected by the periodic acid-Schiff reaction, according to Zacharius et al. (1969).

Determination of protein and nucleic acid. The spectrophotometric method of Warburg \& Christian (1941) was used for the estimation of protein and nucleic acids in column fractions.

Chemicals. Amberlite MB-1, acrylamide, bisacrylamide and ion-exchange cellulose P23 were from Serva, Heidelberg, F.R.G. Pharmalyte, Silan A-174 and Sephadex IEF were from Pharmacia. $S$-Carboxymethylcysteine was from Fluka, Neu-Ulm, F.R.G. All other chemicals were from Merck.

\section{RESULTS}

Properties of the killer toxin of $S$. cerevisiae strain 28

An investigation of 163 yeast strains in the collections of this Institute revealed that of these yeasts only $S$. cerevisiae strain 28 produces a killer toxin. This toxin was found to be most active against the sensitive yeast $S$. cerevisiae strain 67 at pH 5.0. It was later observed that strain 28 was sensitive to several other killer toxin-producing strains of Saccharomyces.

The agar diffusion method (Somers \& Bevan, 1969) was used for the quantitative determination of killer toxin activity. The diameter $(D)$ of the inhibition zone was proportional to the logarithm of the concentration $(\log C)$ of killer toxin for toxin concentrations within the range $0.001-7.0 \mu \mathrm{g} \mathrm{ml}^{-1}$; by contrast, Woods \& Bevan (1968) reported that $D^{2}$ was proportional to $\log C$ for the toxin of $S$. cerevisiae strain D1. An inhibition zone of $11.5 \mathrm{~mm}$ diameter (actual diameter $21.5 \mathrm{~mm}$ minus diameter of the $10 \mathrm{~mm}$ well) was given the arbitrary value of 10000 units of killer toxin activity. Later experiments revealed that $1 \mathrm{mg}$ of pure killer toxin was equivalent to about $10^{7}$ units.

The killer toxins of different yeasts can be distinguished by their $\mathrm{pH}$ optima and temperature stability (or sensitivity). In the genus Saccharomyces the toxin groups $\mathbf{K}_{1}, \mathbf{K}_{2}$ and $\mathbf{K}_{3}$ have been recognized to date (Wickner, 1976; Young \& Yagiu, 1978). The toxin of S. cerevisiae strain 28 probably does not belong to one of these groups. It has a $\mathrm{pH}$ optimum of 5 , whereas the other toxins have been shown to be most active in the $\mathrm{pH}$ range $4 \cdot 2-4 \cdot 8$. Compared with the toxins of other yeasts, the toxin of $S$. cerevisiae strain 28 is very stable. Exposure of a solution of the toxin in buffer at $\mathrm{pH} 5.0$ for $1 \mathrm{~h}$ at $40^{\circ} \mathrm{C}$ did not lower the activity.

\section{Purification of the extracellular killer toxin}

The supernatant of a culture of Saccharomyces cerevisiae strain 28 in 201 of the synthetic Bmedium was concentrated about 2000 -fold by ultrafiltration. By repeated concentration with an Amicon PM10 membrane and dilution with $0.01 \mathrm{M}$-citrate buffer, $\mathrm{pH} 3.5$, crude toxin preparations were desalted to a conductivity of about $0.6 \mathrm{mS}$ and then purified by ion-exchange chromatography. A typical elution diagram is shown in Fig. 1. Killer toxin was first eluted at fraction 22 and maximum activity was found in fractions 27 to 30 , which had a conductivity of approximately $17 \mathrm{mS}$.

Isoelectric focusing of the active fractions on acrylamide in the range $\mathrm{pH} 3-10$ revealed that fractions 27 onwards contained only one band of protein. This protein had an isoelectric point of about $\mathrm{pH} 4 \cdot 4-4 \cdot 5$. The specific killer toxin activity was increased 27-fold from $0.37 \times 10^{5}$ to 1.0 $\times 10^{7}$ units (mg protein) $)^{-1}$. The yield was $82 \%$, corresponding to $6.5 \mathrm{mg}$ protein recovered from 201 medium.

\section{Characterization of the extracellular killer toxin}

Determination of molecular weight. Polyacrylamide gradient gel electrophoresis with appropriate protein standards was used to determine the molecular weight of the killer toxin. The toxin moved in a single band in front of albumin and its molecular weight was estimated to be about 16000 . 


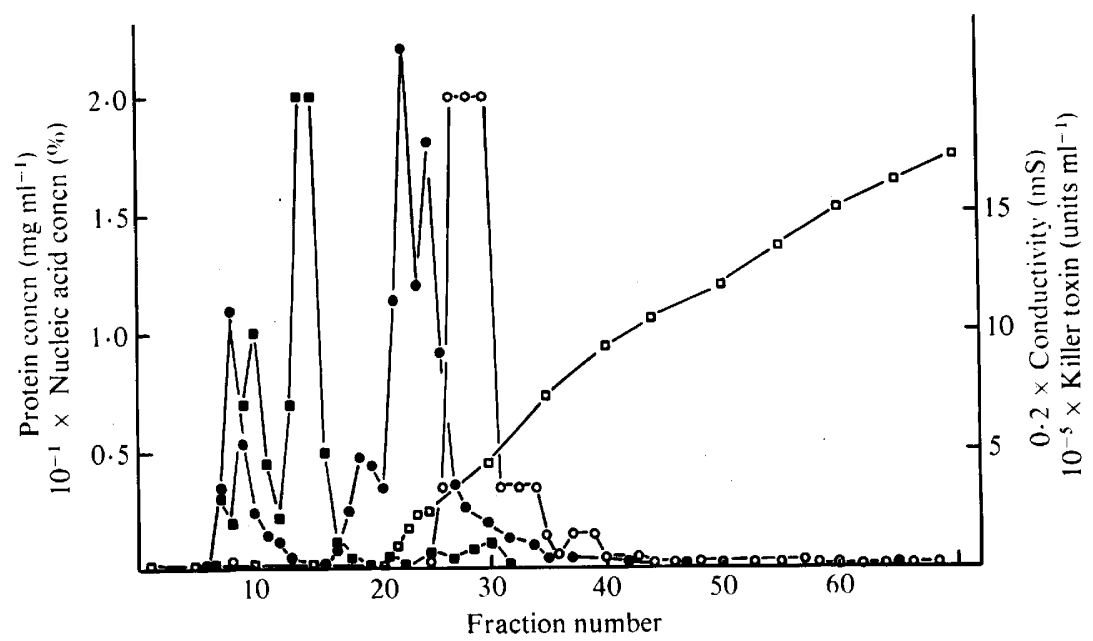

Fig. 1. Purification of the killer toxin of $S$. cerevisiae strain 28 by chromatography on ion-exchange cellulose P23. $\bigcirc$, Activity of killer toxin; $\odot$, protein concentration; $\square$, nucleic acids; $\square$, conductivity; fractions of $6 \mathrm{ml}$ were collected.

$\bigoplus$

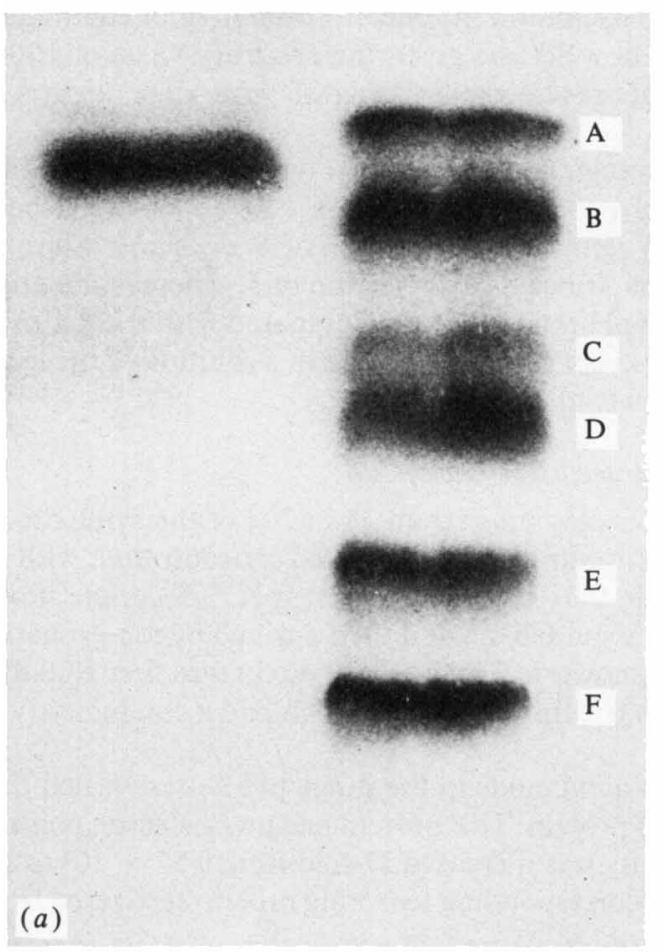

$\Theta$ $\bigoplus$

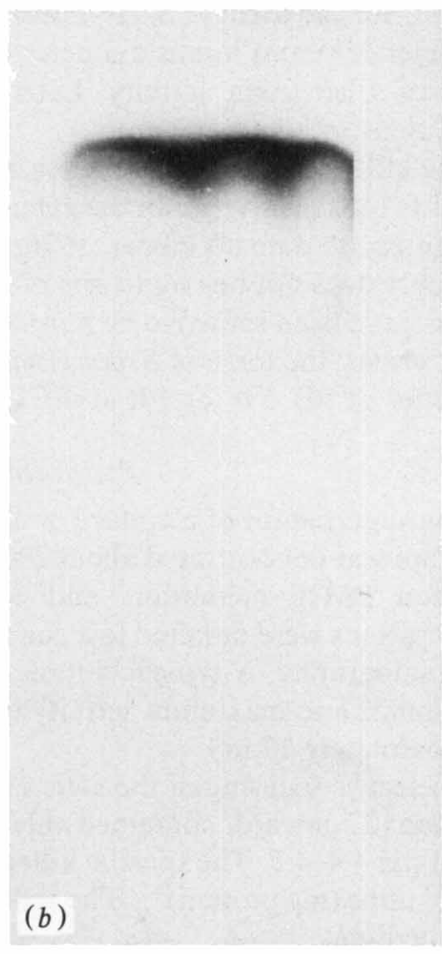

$\Theta$

Fig. 2. (a) SDS-Polyacrylamide gradient gel electrophoresis of purified killer toxin of S. cerevisiae strain 28 (left) and calibration proteins: A, $\alpha$-lactalbumin; B, trypsin inhibitor; C, carbonic anhydrase; D, ovalbumin; E, albumin; F, phosphorylase $b$. (b) Detection of the carbohydrate moiety of the killer toxin of $S$. cerevisiae strain 28 by staining with periodic acid-Schiff reagent after SDS-polyacrylamide gradient gel electrophoresis. 
When SDS-polyacrylamide gradient gel electrophoresis was used, the killer toxin again showed a single protein band after staining. This band had a $R_{F}$ value between trypsin inhibitor (mol. wt 20100) and $\alpha$-lactalbumin (mol. wt 14400) and also corresponded to a molecular weight of about 16000 (Fig. $2 a$ ). Thus it can be assumed that the killer toxin consists of one polypeptide and not of several subunits.

Schiff reagent was used to investigate whether the killer toxin is a glycoprotein. After SDSpolyacrylamide gradient gel electrophoresis, one red band at the $R_{F}$ value $(0 \cdot 78)$ of the killer toxin was detected (Fig. $2 b$ ). This indicated that the killer toxin of S. cerevisiae strain 28 is indeed a glycoprotein.

Amino acid analysis. To determine the amino acid composition of the killer toxin, lyophilized toxin $(0.75 \mathrm{mg})$ was hydrolysed in $6 \mathrm{M}-\mathrm{HCl}$ for $24 \mathrm{~h}$. The analytical results obtained with two samples are summarized in Table 1.

The total number of amino acid residues present was estimated to be 111 , corresponding to a molecular weight of 14045 . Since the value for molecular weight determined by gel electrophoresis was approximately 16000 , this suggests that the toxin of $S$. cerevisiae strain 28 consists of about $90 \%$ protein and $10 \%$ carbohydrate.

Estimation of the concentration of killer toxin necessary to kill sensitive yeasts. An estimate was made of the lowest concentration of killer toxin required to inhibit the growth of the sensitive yeast $S$. cerevisiae strain 67 . For this purpose a series of test tubes containing $10 \mathrm{ml}$ YEP-medium buffered to $\mathrm{pH} 5 \cdot 0$ with $0 \cdot 1 \mathrm{M}$-citric acid and $\mathrm{K}_{2} \mathrm{HPO}_{4}$ were inoculated with $10^{6}$ cells of the sensitive yeast per tube. Killer toxin was added in concentrations from $4.4 \times 10^{-6}$ to $6.3 \times 10^{-3}$ $\mu \mathrm{M}$. After incubation for $3 \mathrm{~d}$ at $20^{\circ} \mathrm{C}$ no growth of the yeast was observed at a concentration of $0.31 \times 10^{-3} \mu \mathrm{M}$ killer toxin. Growth occurred at lower toxin concentrations. At the inhibitory toxin concentration, about $10^{8}$ toxin molecules were present in the medium per yeast cell. The amount of toxin actually absorbed by the sensitive yeast has not been determined.

Table 1. Amino acid analysis of the hydrolysate $(H)$ and the carboxymethylated hydrolysate $(C)$ of extracellular killer toxin of Saccharomyces cerevisiae strain 28

Sample $\mathrm{H}$ contained $0.75 \mathrm{mg}$ hydrolysate $\mathrm{ml}^{-1}$ and sample $\mathrm{C}$ contained $1.5 \mathrm{mg}$ hydrolysate $\mathrm{ml}^{-1}$; tryptophan was estimated by spectrophotometry.

Amino acid

$S$-Carboxymethylcysteine

Aspartic acid

Threonine

Serine

Proline

Glutamic acid

Glycine

Alanine

Valine

Cysteine

Methionine

Isoleucine

Leucine

Tyrosine

Phenylalanine

Tryptophan

Lysine

Histidine

Arginine

$\begin{array}{cc}\overbrace{\text { Sample H }}^{\text {Concn }}\left(\mu \mathrm{mol} \mathrm{ml}^{-1}\right) \\ \text { ND } & 0.24 \\ 0.315 & 0.47 \\ 0.344 & 0.44 \\ 0.401 & 0.46 \\ 0.223 & \text { ND } \\ 0.365 & 0.44 \\ 0.2 & 0.28 \\ 0.406 & 0.52 \\ 0.241 & 0.27 \\ 0 & \text { ND } \\ 0.069 & 0.09 \\ 0.172 & 0.25 \\ 0.243 & 0.33 \\ 0.206 & 0.24 \\ 0.111 & 0.15 \\ 0.079 & \text { ND } \\ 0.116 & \text { ND } \\ 0.069 & \text { ND } \\ 0.117 & \text { ND } \\ \end{array}$

ND, Not determined.
No. of residues per molecule

\begin{tabular}{cc}
\hline Sample H & Sample C \\
ND & $5 \cdot 3$ \\
$9 \cdot 1$ & $10 \cdot 4$ \\
10 & $9 \cdot 8$ \\
$11 \cdot 6$ & $10 \cdot 2$ \\
$6 \cdot 4$ & ND \\
$10 \cdot 6$ & $9 \cdot 8$ \\
5.8 & $6 \cdot 2$ \\
$11 \cdot 8$ & $11 \cdot 6$ \\
7 & 6 \\
0 & ND \\
2 & 2 \\
5 & $5 \cdot 6$ \\
7 & $7 \cdot 4$ \\
6 & $5 \cdot 4$ \\
3.2 & $3 \cdot 4$ \\
2.3 & ND \\
3.4 & ND \\
2 & ND \\
3.4 & ND
\end{tabular}




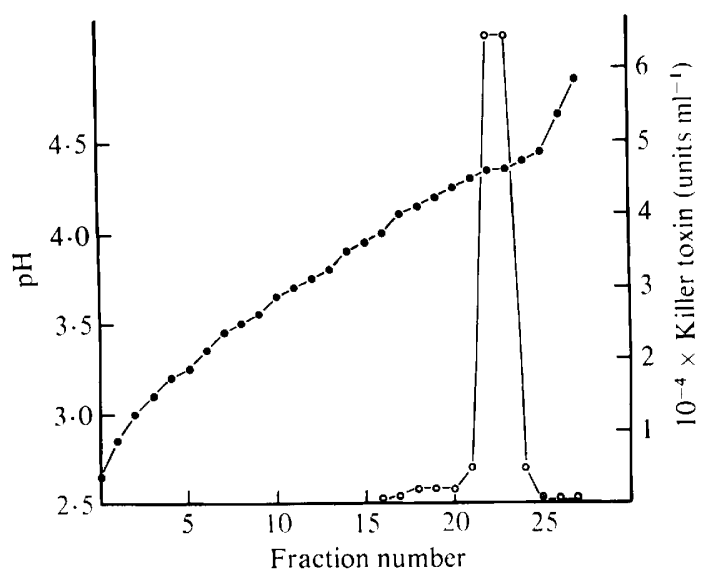

Fig. 3. Determination of the isoelectric point of the intracellular killer toxin of $S$. cerevisiae strain 28 by isoelectric focusing on Sephadex-IEF.

\section{Identification of an intracellular killer toxin}

For the detection of intracellular killer toxin $S$. cerevisiae strain 28 was cultivated in Bmedium. The cells were washed five times with $0.01 \mathrm{M}$-citrate/phosphate buffer, $\mathrm{pH} 5 \cdot 0$, to remove adhering extracellular toxin. A cell extract was obtained by macerating yeast cells $(20 \mathrm{~g}$ wet wt) in $20 \mathrm{ml}$ citrate/phosphate buffer containing $40 \mathrm{~g}$ glass beads (diameter $0.45 \mathrm{~mm}$ ) for 2 min at 4000 r.p.m. in a $\mathrm{CO}_{2}$-cooled MSK homogenizer (Braun, Melsungen, F.R.G.). After homogenization, cell debris and glass beads were removed by centrifugation at $15000 \mathrm{~g}$ for $60 \mathrm{~min}$ at $4{ }^{\circ} \mathrm{C}$. This cell extract was toxic for the sensitive yeast $S$. cerevisiae strain 67 . The extract had a killer toxin activity of $1.5 \times 10^{6}$ units $\mathrm{ml}^{-1}$ when the usual assay was employed.

The isoelectric point of the intracellular toxin was determined as about $\mathrm{pH} 4.35$ by isoelectric focusing in Sephadex-IEF (Fig. 3). This value is very similar to the isoelectric point of the extracellular toxin, suggesting that the intracellular and extracellular killer toxin are probably identical.

Purification of the intracellular toxin was attempted by ultrafiltration (membrane type,

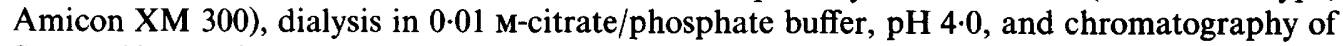
Servacel ion-exchange cellulose P23. The toxin was eluted at a conductivity of about $17 \mathrm{mS}$. This preparation had a specific activity of $3.8 \times 10^{6}$ units $(\mathrm{mg} \text { protein })^{-1}$, representing a 140 -fold purification.

\section{DISCUSSION}

Since the discovery of the killer toxin of yeast by Bevan \& Makower (1963), this phenomenon has been the subject of numerous papers. However, purification of the toxin has proved difficult. Woods \& Bevan (1968) reported that the toxin was adsorbed by Sephadex 'and was thus not fractionated by gel filtration with Sephadex G-150'. Because of a broad distribution of the killer toxin in many fractions after gel filtration on Sepharose 4B, Bussey (1972) assumed that the toxin consists of a multi-compound complex. Later Palfree \& Bussey (1979) succeeded in the purification of the killer toxin of $S$. cerevisiae strain $\mathrm{T} 158 \mathrm{C}$, but they concluded from the distribution of the toxin in many fractions that a polymerization might take place at increasing concentrations.

Our preliminary experiments with the extracellular killer toxin of $S$. cerevisiae strain 28 showed that this toxin could not be purified by gel filtration with Sepharose or Sephadex. Purification of the toxin was greatly simplified by the use of a synthetic growth medium for the yeast. Peptone or yeast extract, which were previously thought to be important for the production of active toxin (Woods \& Bevan, 1968; Palfree \& Bussey, 1979) were not essential for toxin production by strain 28 . A 2000 -fold concentration of the toxin could therefore be achieved by ultrafiltration of culture supernatants. The crude concentrated material was then purified by 
ion-exchange chromatography. The yield of pure toxin was approximately eight times that obtained by Palfree \& Bussey (1979) for the toxin of strain T 158C. In our purification procedure the use of detergents and precipitation of the toxin were avoided. We believe that with this simple method a pure and possibly unaltered toxin is obtained. It is assumed that if the toxin consists of several components, the non-toxic components have not been removed by our procedure.

The toxin isolated by Palfree \& Bussey (1979) from S. cerevisiae strain T $158 \mathrm{C}$ and the killer toxin described in this paper are obviously different, although similarities can also be observed. The total number of amino acid residues in each case is almost identical (111 and 109), but due to differences in amino acid composition, the calculated molecular weights differ greatly (14045 and 11470 ). The toxin of our strain 28 contains all 20 known amino acids, whereas no arginine or proline was reported for the toxin of strain $\mathrm{T} 158 \mathrm{C}$. We assume that the toxin described in this paper contains about $10 \%$ carbohydrate. No or almost no carbohydrate was reported for the toxin of strain T $158 \mathrm{C}$. However, this latter toxin was treated with $4 \mathrm{M}$-urea, which might have caused removal of carbohydrate without inactivation of the toxin. We have not attempted to separate or to analyse the carbohydrate moiety of the toxin of strain 28 .

Most publications have so far dealt only with the extracellular killer toxin of yeasts. The cytoplasm of toxin-producing yeasts often does not appear to contain detectable amounts of toxin. This was observed in an investigation of several different toxin-producing strains; cellfree extracts of these strains were inactive (P. Pfeiffer \& F. Radler, unpublished observations). However, the cell extract of $S$. cerevisiae strain 28 showed killer toxin activity; this toxin was comparatively stable at the usual $\mathrm{pH}$ value $(5 \cdot 5-5 \cdot 7)$ of yeast cytoplasm.

It was of interest to compare the concentrations of extracellular and intracellular killer toxin. The concentration of toxin in the culture medium (extracellular toxin) was about 4000 units $\mathrm{ml}^{-1}$. Undiluted cell extract contained about $4 \times 10^{6}$ units killer toxin $\mathrm{ml}^{-1}$; this corresponds to about $4 \times 10^{-4}$ units per yeast cell, if a volume of $10^{-10} \mathrm{ml}$ is assumed for one cell. Thus the intracellular concentration of killer toxin is about 1000 times higher than the extracellular concentration.

The intracellular toxin of the other yeast strains may have been destroyed during extraction. It is likely that the intracellular and extracellular killer toxins of $S$. cerevisiae strain 28 are identical, because of their similar isoelectric points. Thus it appears that the killer toxin of this strain is produced intracellularly and is liberated in an unmodified form by the yeast cells.

The work was kindly supported by a grant from the Deutsche Forschungsgemeinschaft.

\section{REFERENCES}

Bevan, E. A. \& Makower, M. (1963). The physiological basis of the killer-character in yeast. Proceedings of the 11th International Congress of Genetics 1, 203 (abstract).

Bostian, K. A., Sturgeon, J. A. \& Tipper, D. J. (1980). Encapsidation of yeast killer double-stranded ribonucleic acids: dependence of $\mathbf{M}$ on $\mathbf{L}$. Journal of Bacteriology 143, 463-470.

BuSSEY, H. (1972). Effects of yeast killer factor on sensitive cells. Nature New Biology 235, 73-75.

BusSEY, H. (1981). Physiology of the killer factor in yeast. Advances in Microbial Physiology 22, 93122.

BuSSEY, H. \& SHERMAN, D. (1973). Yeast killer factor : ATP leakage and coordinate inhibition of macromolecular synthesis in sensitive cells. Biochimica et biophysica acta 298, 868-875.

BuSSEY, H. \& SkIPPER, N. (1975). Membrane-mediated killing of Saccharomyces cerevisiae by glycoproteins from Torulopsis glabrata. Journal of Bacteriology 124, 476-483.
De la Pena, P., Borros, F., Gascon, S., Lazo, P. S. \& Ramas, S. (1981). Effect of yeast killer-toxin on sensitive cells of Saccharomyces cerevisiae. Journal of Biological Chemistry 256, 10420-10425.

Goodwin, T. W. \& Morton, R. A. (1946). The spectrophotometric determination of tyrosine and tryptophane in proteins. Biochemical Journal 40, 628-632.

Heerde, E. \& Radler, F. (1978). Metabolism of the anaerobic formation of succinic acid by Saccharomyces cerevisiae. Archives of Microbiology 117, 269276.

Herring, A. J. \& Bevan, E. A. (1974). Virus-like particles associated with the double-stranded RNA species found in killer and sensitive strains of the yeast Saccharomyces cerevisiae. Journal of General Virology 22, 387-394.

Kotani, H., Shinmyo, A. \& Enatsu, T. (1977). Killertoxin for sake yeast: properties and effects of adenosine-5'-diphosphate and calcium-ion on killing action. Journal of Bacteriology 129, 640-650. 
MAKOWER, M. \& BevaN, E. A. (1963). The inheritance of a killer character in yeast (Saccharomyces cerevisiae). Proceedings of the 11th International Congress of Genetics 1, 202 (abstract).

Middelbeex, E. J., Hermans, J. M. H. \& Stumm, C. (1979). Production, purification and properties of a Pichia kluyveri killer toxin. Antonie van Leeuwenhoek 45, 437-450.

Palfree, G. E. \& Bussey, H. (1979). Yeast killer-toxin. Purification and characterization of the protein toxin from Saccharomyces cerevisiae. European Journal of Biochemistry 93, 487-493.

SKIPPER, N. \& BUSSEY, H. (1977). Mode of action of yeast toxins: energy requirement for Saccharomyces killer-toxin. Journal of Bacteriology 129, 668-677.

Somers, J. M. \& Bevan, E. A. (1969). The inheritance of the killer-character in yeast. Genetical Research $13,71-84$.

VESTERBERG, O. (1972). Isoelectric focusing of proteins in polyacrylamide gels. Biochimica et biophysica acta 257, 11-19.

VodkIN, M. H. \& FINK, G. R. (1973). The killer factor of yeast and a double-stranded RNA associated with it. Genetics 74, 286.

Vodkin, M. H., Kattermann, F. \& Fink, G. R. (1974). Yeast killer mutants with altered double- stranded ribonucleic acid. Journal of Bacteriology 117, 681-686.

WarburG, O. \& Christian, W. (1941). Isolierung und Kristallisation des Gärungsfermentes Enolase. Biochemische Zeitschrift 310, 384-421.

WEBER, K. \& OsBoRN, M. (1969). The reliability of molecular weight determinations by dodecyl sulfatepolyacrylamide gel electrophoresis. Journal of Biological Chemistry 244, 4406-4412.

WICKNER, R. B. (1976). Killer of Saccharomyces cerevisiae: a double-stranded RNA plasmid. Bacteriological Reviews 40, 757-773.

Woods, D. R. \& Bevan, E. A. (1968). Studies on the nature of the killer factor produced by Saccharomyces cerevisiae. Journal of General Microbiology 51, 115-126.

Woods, D. R., Ross, I. W. \& Hendry, D. A. (1974). A new killer factor produced by a killer/sensitive yeast strain. Journal of General Microbiology 81, 285-289.

YounG, T. W. \& YAGIU, M. (1978). A comparison of killer character in different yeasts and its classification. Antonie van Leeuwenhoek 44, 59-77.

Zacharius, R. M., Zell, T. E., MORRISON, J. H. \& WoODLOCK, J. J. (1969). Glycoprotein staining following electrophoresis on acrylamide gels. Journal of Analytical Biochemistry 30, 148-152. 